\title{
Vitamin D, calcium and phosphorus status in children with short stature - effect of growth hormone therapy
}

\author{
Maria Klatka' ${ }^{1, A-B, D, F} \oplus$, Małgorzata Partyka ${ }^{2, A, D-E} \oplus$, Agnieszka Polak ${ }^{3, D-E \oplus}$, Barbara Terpiłowska ${ }^{4, B-D \oplus}$, \\ Michał Terpiłowski ${ }^{4, B-D \oplus,}$, Renata Chałas ${ }^{5, E-F} \odot$ \\ ${ }^{1}$ Department of Paediatric Endocrinology and Neurology, Medical University, Lublin, Poland \\ ${ }^{2}$ Department of Orthodontics, Medical University, Lublin, Poland \\ ${ }^{3}$ Department of Endocrinology, Medical University, Lublin, Poland \\ ${ }^{4}$ Students' Scientific Society, Chair and Department of Jaw Orthopaedics, Medical University, Lublin, Poland \\ ${ }^{5}$ Department of Oral Medicine, Medical University, Lublin, Poland \\ A - Research concept and design, B - Collection and/or assembly of data, C - Data analysis and interpretation, \\ $D$ - Writing the article, E-Critical revision of the article, F-Final approval of the article
}

Klatka M, Partyka M, Polak A, Terpiłowska B, Terpiłowski M, Chałas R. Vitamin D, calcium and phosphorus status in children with short stature - effect of growth hormone therapy. Ann Agric Environ Med. 2021; 28(4): 686-691. doi: 10.26444/aaem/139569

\begin{abstract}
Objective. The aim of the study was to assess the level of calcium, phosphorus and vitamin D in the blood of patients treated for short stature (SS).

Materials and method. The study encompassed 110 children treated for somatotropin hypopituitarism (SHP) in the Department of Paediatric Endocrinology and Diabetology at the Medical University of Lublin. The levels of calcium, phosphorus and vitamin D were marked for both groups in the peripheral blood collected on a routine basis for diagnostic examinations. The parameters were compared within the group of children with SHP, both the patients who were about to start the therapy and those in the course of the therapy as well as between the research group (110 children) and the control group.

Results. The results obtained were compared with the results in the control group that comprised 41 children with a general good health status, although with nasal septum deviation treated in the Department of Paediatric Otolaryngology at the Medical University of Lublin.

Conclusions. On the basis of the research performed, the following conclusions were drawn: 1) children with SHP were characterised with calcium-phosphorus imbalance. The level of calcium, phosphorus and vitamin D was diminished. The values did not change due to a several-year hormone growth treatment (HGT). 2) the level of calcium and phosphorus was appropriate in the control group children, but the vitamin D level was considerably lowered. This shows the necessity for vitamin D control and supplementation, not only in children with SS.
\end{abstract}

\section{Key words}

vitamin D, phosphorus, calcium, growth hormone therapy

\section{INTRODUCTION}

Calcium (Ca), phosphorus (P) and vitamin D play a pivotal role in the developing organism of a child. They constitute the building material of the bones and teeth. Insufficient food intake considerably contributes to the inappropriate development of bones and teeth, rickets, and tooth decay, and negatively affects the overall development of a child. The appropriate level of calcium in the body depends not only on its food supply/food intake, but also on its absorption. The range of $10-40 \%$ of calcium consumed with food is absorbed in the digestive tract. Vitamin D plays an important role as it facilitates building up calcium in the bone [1]. The most significant supply of calcium takes place in childhood and adolescence, since the organism endeavours to reach the highest level of bone mass.

Apart from calcium, phosphorus is also an important building component for bones and teeth. It is present in

Address for correspondence: Maria Klatka, Department of Paediatric Endocrinology and Neurology, Medical University of Lublin, Poland

E-mail: mariaklatka@wp.pl

Received: 19.03.2021; accepted: 22.06.2021; first published:07.07.2021 the body mainly in combination with oxygen in the form of phosphates $\left(\mathrm{PO}_{4}\right)$. The presence of calcium and vitamin $\mathrm{D}$ intensifies the activity of phosphates which are found in food; thus, its insufficiency in the body is rare. Long-lasting lack can lead to rickets and decalcification of bones. Calcium and phosphorus play important roles in many biological processes, and studies have shown that they may have a positive regulatory role in cell growth and proliferation. Calcium is needed for muscle contraction, hormone release, blood clotting concatenation and neuronal excitation. Phosphorus is involved in the body's energy metabolism, nucleic acid synthesis, and cell signalling conduction and cell membrane stabilization [2]. The regulation of calcium and phosphates concentration in the serum depends on the combined activity of the parathyroid hormone $(\mathrm{PTH})$, vitamin D and calcitonin. Growth hormone $(\mathrm{GH})$, prolactin, glucocorticosteroids, thyroid hormones, prostaglandins, and somatomedins have an additional influence on calcium and phosphates metabolism [3].

The issue of vitamin D insufficiency concerns many countries, both those with a lower level of medical care and those with appropriate prevention of vitamin D insufficiency. 
The earliest prodrome of its shortage occurs at the age of two and during puberty [4]. Vitamin $\mathrm{D}_{3}$ which is produced in the integumentary system due to the sun's rays, is a provitamin that activates itself after a two-step process taking part in the body [5]. The first part of the process, called hydroxylation, takes place in the liver on carbon-25 to yield 25-hydroxyvitamin D $25(\mathrm{OH}) \mathrm{D}_{3}$ which is carried to the blood circulation [6]. The other step of hydroxylation takes place in the kidneys on carbon-1 under the influence of 1 alphahydroxylase to active hormone $1,25(\mathrm{OH})_{2} \mathrm{D}$ representing the characteristic activity of vitamin D [7]. Hydroxylation in the kidneys is controlled by $\mathrm{PTH}, \mathrm{Ca}$ and $\mathrm{P}$, as well as other hormones. Vitamin D receptors (VDR) participate in the activity of vitamin $\mathrm{D}$ and they act like transcription factors. The receptor mechanism enables vitamin $\mathrm{D}$ to regulate mineral homeostasis in the organism. Due to vitamin $1,25(\mathrm{OH})_{2} \mathrm{D}$, the absorption of calcium and phosphorus in the intestines is possible, though it is less dependent on the vitamin in the case of phosphorus than calcium. If there is vitamin D deficiency, the absorption of calcium is considerably greater than that of phosphorus. Vitamin $1,25(\mathrm{OH})_{2}$ D affects the proliferation of healthy and cancerous tissue. It has an immunomodulating function which has been confirmed by long-term clinical observation of children with vitamin $\mathrm{D}$ deficiency who more frequently contracted many infections [8].

Short stature (SS) - disorders of height and development. The process of growth relies on increasing the measurements and development of organs that leads to the change of body proportions, from those typical for children to those typical for adults. The order of growth stages is genetically determined and each takes places after the completion of the previous one. The secretion of growth hormone $(\mathrm{GH})$ by the pituitary is pulsating, and the frequency as well as intensity of the impulses depend on age and gender. Physiological impulses affecting GH secretion include, among others, hunger, physical effort, sleep and stress. During sleep, the pituitary releases around $70 \%$ of the twenty-four-hour amount of hormone. Somatotropin influences tissues to stimulate harmonious growth of all organs [9].

Therefore3, SS is defined as body height below the 3rd percentile on a percentile grid, or below 2 standard deviations (-2SD) from the mean for a particular population. The problem involves roughly $3 \%$ of children [10].

$\mathrm{GH}$ is known to affect body composition, bone mineralization, as well as lipid and glucose metabolism. The condition of GH deficiency (GHD) has been accepted as a definite syndrome, and the clinical and biochemical abnormalities in GHD patients are also well known. They involve mainly the cardiovascular system, lipid metabolism, body composition, mineral metabolism, and quality of life $[11,12]$

Growth rate depends on absorption of nutrients. Inappropriate intake of many nutrients, including calcium, phosphorus and vitamin $\mathrm{D}$, can negatively influence the mineralisation and growth of bones [13]. There is a great deal of concern regarding calcium, phosphorus and vitamin $\mathrm{D}$ intake, as well as biochemical changes in children and adolescents, which resulted in the current investigate into the levels of calcium, phosphorus and vitamin D during growth. Calcium has a major role in the development and maintenance of peak bone mass during childhood and adolescence, as well as in the subsequent prevention of osteoporosis. Calcium absorption and bone calcium accretion are affected by dietary calcium and vitamin D status. The former can be assessed by dietary history and the latter by the serum concentration of $25(0 \mathrm{H}) \mathrm{D}_{3}$ [14]. Phosphorus is found in food; thus, its insufficiency in the body is rare. Long-lasting lack can lead to rickets, decalcification of the bones and growth disorders [2].

\section{OBJECTIVE}

The aim of the study was assessment of the calcium, phosphorus and vitamin D levels in the blood of patients diagnosed and treated for short stature (SS) in the Department of Endocrinology and Paediatric Diabetology at the Medical University of Lublin, compared with a control group.

\section{MATERIALS AND METHOD}

Characteristics of the research and control groups. The study encompassed 110 children ( 27 girls and 83 boys) with somatotropinic hypopituitarism (SHP), hospitalized in the Department of Paediatric Endocrinology and Diabetology at the Medical University of Lublin.

A total of 47 children (43\%), who had their GH treatment initiated (SHP group was about to start the treatment), and 63 children (57\%), who had been treated for 2-3 years (SHP group in the course of the treatment) constituted the research sample. Selected parameters were assessed in both groups.

The control group consisted of 41 children with nasal septum deviation, also hospitalized in the Department of Paediatric Otolaryngology at the Medical University of Lublin. In the group of patients with SS, the mean calendar age was 13 years, with a standard deviation of 2 years and 6 months. In the control group, the mean calendar age was 11 years and 5 months, with a standard deviation of 2 years and 5 months. The same parameters were assessed in the control group.

The research was approved by the Bioethics Committee at the Medical University of Lublin (No. KE-0254/216/2015).

Research methods. The levels of calcium, phosphorus and vitamin D in the group of children with SS and the control group were assessed in the peripheral blood collected on a routine basis for diagnostic examinations. The assessment of calcium concentration was performed with an analyzer Arsenawo III in the Laboratory of Medical Analyses ALAB of the Independent Public Clinical Hospital No. 4 in Lublin. Phosphorus concentration was determined by means of the spectrophotometric method with ammon molibdenite with sulphuric acid in the Laboratory of Medical Analyses ALAB of the Independent Public Clinic Hospital No. 4 in Lublin. The total concentration of $25(\mathrm{OH}) \mathrm{D}_{3}$ was determined with the Cobas 411 Analyzer by Roche Diagnostic in the Laboratory of Medical Analyses ALAB of the Independent Public Clinical Hospital No. 4 in Lublin.

Statistical analysis. The research results were introduced into the spreadsheet Microsoft Excel 2010. The statistical analysis was conducted using Statistica 10 (Statsoft Inc., USA). 


\section{RESULTS OF LABORATORY EXAMINATIONS}

Calcium level. The normal range for the blood calcium level in children above 1 year of age is $8.4-10.4 \mathrm{mg} / \mathrm{dl}(2.20-2.78$ $\mathrm{mmol} / \mathrm{l}$ [ [15]. In the control group, the mean level of calcium was $8.92 \mathrm{mg} / \mathrm{dl}$ with a standard deviation of 1.63 ; median - 9.30. In the control group, 32 patients (82\%) had their calcium level within the normal limits, but in 7 patients $(18 \%)$, the level of calcium was below the norm. The range of confidence interval for the mean was 8.39-9.45. Student's $\mathrm{t}$-test for the mean value did not show that the level of calcium was significantly lower than the minimum limit.

In the group of patients with SS, the mean value of calcium was $2.46 \mathrm{mg} / \mathrm{dl} \pm 0.11$; median value -2.46 . In the group of patients with SS, 108 patients (100\%) had the level of calcium below the minimum limit. The range of confidence interval for the mean value was 2.44-2.48. Student's $t$ test for the mean value showed that the level of calcium was significantly lower than the minimum limit $(\mathrm{p}=0.000)$.

Phosphorus level. The normal range for blood phosphorus level in children above 1 year of age is $3.4-6.2 \mathrm{mg} / \mathrm{dl}$ $(1,10-2,0 \mathrm{mmol} / \mathrm{l})[16]$. In the control group, the mean level of phosphorus was $4.12 \mathrm{mg} / \mathrm{dl} \pm 0.89$; median -4.30 .

In the control group, 34 patients $(87 \%)$ had their phosphorus level within the normal range, but in 5 patients (13\%), the level of phosphorus was below the norm. The range of confidence interval for the mean was 3.84-4.41. Student's t-test for the mean value did not show that the level of phosphorus was significantly lower than the minimum limit.

Level of vitamin $\mathrm{D}\left(\mathbf{2 5}(\mathrm{OH}) \mathrm{D}_{3}\right)$. The normal range for blood Vitamin D level is 30-80 ng/dl [17]. In the control group, the mean level of vitamin $\mathrm{D}$ was $16.75 \mathrm{ng} / \mathrm{dl} \pm 6.16$; median was 16.30. In the control group, 2 patients (5\%) had their vitamin D level within the normal range, but in 35 patients (95\%), the level of phosphorus was below the norm. The range of confidence interval for the mean was 14.69-18.80. Student's $\mathrm{t}$-test for the mean value showed that the level of vitamin $\mathrm{D}$ was significantly lower than the minimum limit $(\mathrm{p}=0.000)$.

In the group of patients with SS, the mean level of vitamin $\mathrm{D}$ was $25.67 \mathrm{ng} / \mathrm{ml} \pm 10.32$; median -24.90 . In the group of patients with SS, 31 patients (29\%) had their vitamin D level within normal limits and 76 patients $(71 \%)$ had vitamin D level below the minimum limit. The range of confidence interval for the mean was 23.70-27.65. Student's t-test for the mean value showed that the level of vitamin $\mathrm{D}$ was significantly lower than the minimum limit $(\mathrm{p}=0.000)$.

Significant differences in the level of calcium, phosphorus and vitamin D were found between the control group and the group of patients with SS. The level of calcium and phosphorus in patients with SS was significantly lower than the level of calcium and phosphorus in the control group $(\mathrm{p}=0.000)$ (Fig. 1, Fig. 2). Differences in mean values were 6.46 and 2.58 , respectively. The level of vitamin $\mathrm{D}$ in patients with SS was significantly higher than the vitamin level in the controls $(\mathrm{p}=0.000)$. The difference in mean values was 8.92 (Fig. 3).

Level of calcium, phosphorus and vitamin $D$ in patients with SS, according to the stage of treatment. In the group of patients with SS, no statistically significant differences were found in the mean level of calcium, phosphorus and

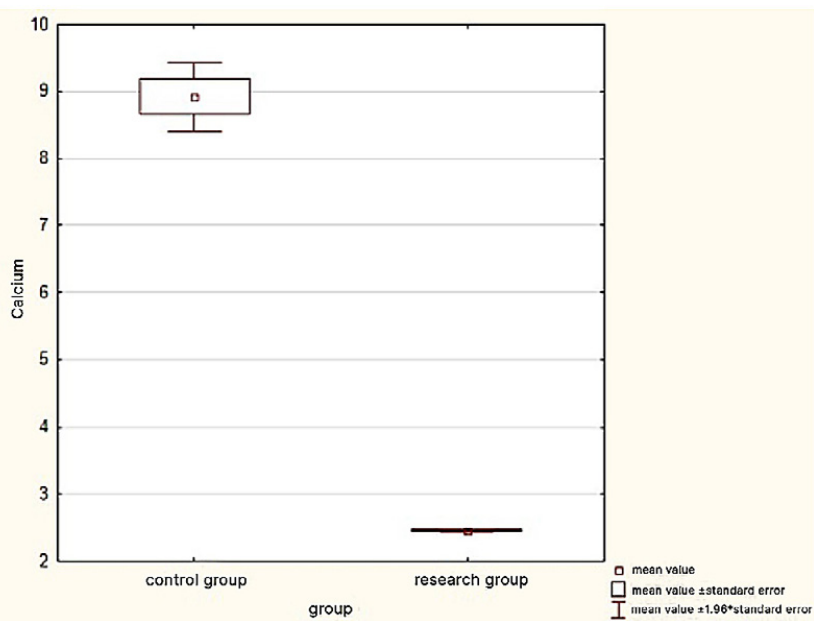

Figure 1. Mean and standard error of calcium level in the control group and group of patients with SS $(\mathrm{p}=0.000)$

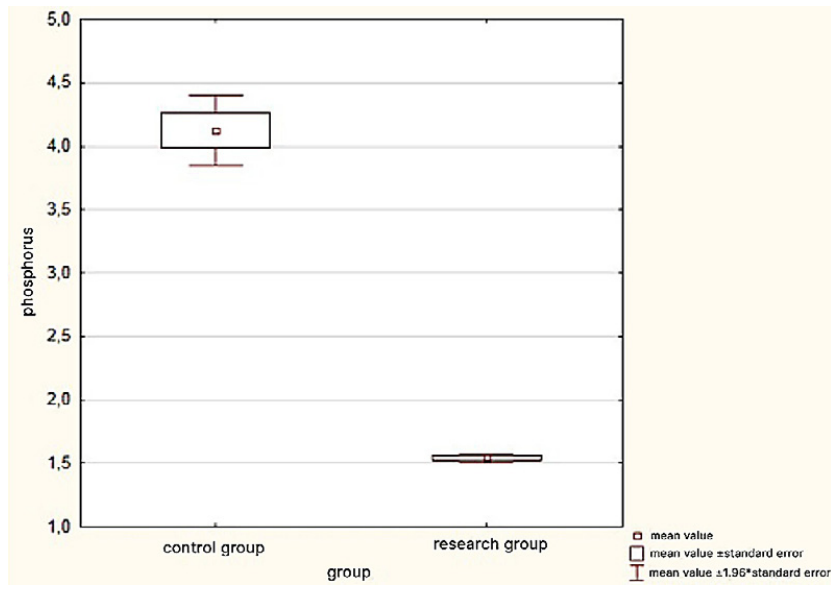

Figure 2. Mean and standard error of phosphorus level in the control group and group of patients with SS $(p=0.000)$

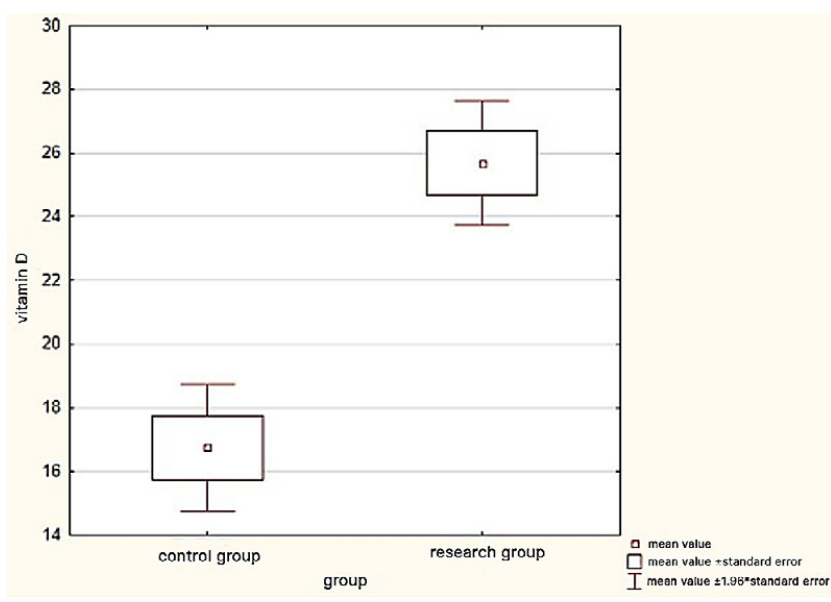

Figure 3. Mean value and standard error of the level of vitamin $D$ in the control group and the group of patients with SS $(p=0.000)$

vitamin $\mathrm{D}$ dependent on the stage of treatment (in all cases $\mathrm{p}>0.05$ ). Detailed values of the mean and standard deviation for each group are shown in Table 1. 
Table 1. Mean values and standard deviation of the level of calcium, phosphorus and vitamin D in the group of patients with SS, dependent on the stage of treatment

\begin{tabular}{lcc}
\hline & \multicolumn{2}{c}{ Stages of treatment } \\
\hline Parameter & SHP in the course of treatment & SHP about to start treatment \\
\hline Calcium & $2.46 \pm 0.13 \mathrm{mmol} / \mathrm{l}$ & $2.49 \pm 0.09 \mathrm{mmol} / \mathrm{l}$ \\
\hline Phosphorus & $1.53 \pm 0.22 \mathrm{mmol} / \mathrm{l}$ & $1.56 \pm 0.13 \mathrm{mmol} / \mathrm{l}$ \\
\hline Vitamin D & $26.42 \pm 11.42 \mathrm{ng} / \mathrm{dl}$ & $24.01 \pm 9.42 \mathrm{ng} / \mathrm{dl}$
\end{tabular}

\section{DISCUSSION}

Human development is a complex mechanism dependent on genetic, environmental, nutritional and hormonal factors. The main hormone involved in growth at all stages of development is growth hormone $(\mathrm{GH})$, and its mediator, insulin-like growth factor 1 (IGF-1). Vitamin D, on the other hand, is involved in the processes of bone growth and mineralization by regulating calcium and phosphorus metabolism. Nevertheless, no scientific study has yet made it clear how they interact, especially as a dysfunction where one affects the other, even though numerous biochemical and clinical studies support a close relationship [18].

Vitamin D is a steroid playing a crucial role in the regulation of calcium and phosphorus levels in the organism that affects the appropriate development and density of the bones, as well as the condition of the teeth [19]. Significant differences in the level of calcium, phosphorus and vitamin $\mathrm{D}$ were found between the control group and the group of patients with SS. The level of calcium and phosphorus in patients with SS was significantly lower than the level of calcium and phosphorus in the control group $(p=0.000)$. Differences in mean values were 6.46 and 2.58 , respectively. The level of vitamin D in patients with SS was significantly higher than the vitamin level in the controls $(p=0.000)$. The difference in mean values was 8.92.

Rickets, both vitamin D dependent and vitamin D resistant, constitutes a genetically conditioned metabolic disorder in children. In the research by Gordom et al. [20], vitamin $\mathrm{D}$ deficiency was present in many US adolescents in an urban clinic-based sample. Research by Ross found that the prevalence of vitamin D deficiency was highest in African-American teenagers during winter, although the problem seemed to be common across genders, seasons, and ethnicity [1]. Żak et al. [21] researched 120 children and youths aged 7-21 years treated for SHP, in which the assessment of blood calcium and phosphates concentration was carried out. The mean values remained within normal limits before treatment and did not differ, namely, statistically significant after the introduction of hormonal therapy: calcium $9.1+/-0.2 \mathrm{mg} / \mathrm{dl}$ vs. $10.11+/-0.57 \mathrm{mg} / \mathrm{dl}$, phosphorus $4.38+/-0.45 \mathrm{mg} / \mathrm{dl}$ vs. $4.53+/-0.55 \mathrm{mg} / \mathrm{dl})$. Minghui et al. [2] described a positive correlation between IGF-1 and serum calcium, and a non-linear relationship between IGF-1and serum phosphorus by adjusting for potential confounding factors in children and adolescents with short stature. This finding suggests that serum calcium and phosphorus levels in children and adolescents with short stature may affect IGF-1 concentrations. Calcium is a crucial mineral component in the organism, $99 \%$ of its systemic quota is localised, along with phosphorus in the bones, in the form of hydroxyapatite.
Studies by Sun et al. [22] demonstrated that in Chinese children and adolescents with short stature, circulating calcium and phosphorus concentrations may be associated with the regulation of IGF-1 levels, and this relationship merits further investigation. Khadilkar et al. [23] proved that calcium and vitamin D supplementation has a positive influence on an increase in bone minerals in children with SHP who were treated with GH. The levels of calcium, phosphorus and vitamin $\mathrm{D}$ were found to change, dependent on the stage of GHT. Statistical analysis showed that it does not change in the course of the treatment (in all the cases $\mathrm{p}>0.05$ ). The research results obtained in the control group seem to be worrying since blood vitamin D level was considerably lowered in the children compared to the normal range of $14.69-18.80 \mathrm{ng} / \mathrm{ml}$ (norm $30-80 \mathrm{ng} / \mathrm{ml}$ ). Dura- Trave et al [24] noticed that GH treatment, at least during the first 2 years, does not modify the vitamin D levels. Vitamin D deficiency could condition the response to GH therapy so vitamin D monitoring should be considered as part of the routine evaluation of children with $\mathrm{GH}$ treatment.

Although the correlation between vitamin $\mathrm{D}$ and growth hormone $(\mathrm{GH})$-insulin-like growth factor 1 (IGF1) axis is documented, to-date, few and conflicting studies have prospectively analyzed vitamin D before and after GH treatment. The aim of Ciresi's research was to evaluate how the condition of GH deficiency (GHD) or GH treatment influences vitamin D in children. They obtained similar results; their research demonstrated a very high prevalence of hypovitaminosis D in Sicilian GHD children, with an improvement after 12 months of GH treatment. Vitamin D assessment should therefore be considered routinely in GHD children both at diagnosis and during the follow-up [25].

The results of studies by Savanelli et al. indicate more frequent occurrence of vitamin $\mathrm{D}$ deficiency in patients with SHP than in healthy people [26]. Karczmarewicz et al., analyzing the studies conducted to-date in various age groups in the population of children in Poland, investigated whether children suffering from SHP are at risk of vitamin D deficiency, in the same way as healthy children [27]. Rasha Tarif Hamza et al. in their studies found that hypovitaminosis D is common in children with GHD, and improved significantly 1 year after GH therapy. The authors agree that $25(\mathrm{OH}) \mathrm{D}_{3}$ should be assessed in children with GHD at diagnosis and during follow-up [28].

There are significant differences in the recommendations for optimal vitamin D concentration. Veugelers et al. [29] took a dual approach to answer this question: 1 ) they collected 108 published estimates of vitamin D supplementation and vitamin D status, and 2) analyzed 13,987 observations of programme participants. An aggregation of the published data showed that 2909 IU vitamin D per day are needed for a serum 25 -hydroxyvitamin $\mathrm{D}\left(25(\mathrm{OH}) \mathrm{D}_{3}\right)$ concentration of 50 $\mathrm{nmol} / \mathrm{L}$, or greater in $97.5 \%$ of healthy subjects. For normal weight, overweight and obese participants, the figures were $3,094,4,450$, and 7,248 IU, respectively. These supplementation doses would also result in $2.5 \%$ normal weight, overweight and obesity with $25(\mathrm{OH}) \mathrm{D}_{3}$ concentrations above 210,200 , and $214 \mathrm{nmol} / \mathrm{L}$, respectively. As these concentrations are high, a risk minimization approach for both low and high concentrations appears desirable. With this approach, it was estimated, for example, that doses of $1,885,2,802$, and 6,235 IU per day are required for normal weight, overweight and obese people, respectively, to achieve the natural $25(\mathrm{OH}) \mathrm{D}_{3}$ 
concentration (defined as 58-171 nmol / L). Overall, the wide variability in $25(\mathrm{OH}) \mathrm{D}_{3}$ concentrations makes the RDA for vitamin $\mathrm{D}$ neither desirable nor feasible. Paramouti et al. [30] report that the difference in the American Institute of Medicine's recommendations and the American Endocrine Society's Practice Guidelines reflect different goals and views on the current evidence. Significant gaps still exist in the literature and research into vitamin $\mathrm{D}$ treatment is needed to evaluate changes in outcomes at different $25(\mathrm{OH}) \mathrm{D}$ levels.

The problem of vitamin $\mathrm{D}$ deficiency occurs in many countries, both those with a relatively low quality of medical care and those with appropriate prevention of vitamin D deficiency $[31,32]$. Surprisingly, there are many research reports on commonly-known hypovitaminosis of vitamin $\mathrm{D}$ also in people well-exposed to the sun because of their place of residence $[33,34]$. This unexpected phenomenon is explained by a change of lifestyle. Nowadays, the period of sun exposure in children has been considerably lowered.

Vitamin D deficiency resulting from reduced activation of the acquired immune system can lead to, among other things, disorders of the immune system such as diabetes type 1 , asthma, rheumatoid arthritis and multiple sclerosis [35, $36,37,38]$. Neoplasms, blood vessel disorders, diabetes type 2 , obesity and hypertension $[39,40]$ are increasingly more frequently attributed to, among other things, an insufficient level of vitamin D in the body. Based on the results of the authors' own research and that of many other researchers, the assessment of blood vitamin D level, and if necessary its supplementation, are of great significance in the era of vitamin D deficiency [41].

\section{CONCLUSIONS}

On the basis of the aforementioned research, the following conclusions were drawn:

1. Children with SHP are characterised by calcium and phosphorus imbalance. The levels of calcium, phosphorus and vitamin $\mathrm{D}$ were lowered and did not change due to several-year GHT.

2. The levels of calcium and phosphorus were appropriate in children from the control group; however, vitamin D level was considerably lowered. This shows the necessity for controlling the blood vitamin D level and possible supplementation, not only in children with SS.

\section{REFERENCES}

1. Ross AC. Institute of Medicine (U.S), eds. Dietary Reference Intake: Calcium, Vitamin D. Washington, DC: National Academies Press; 2011.

2. Minghui S, Wenhua Y, Qianqian Z, Baolan J, Bo B, Mei Z. Association between serum calcium and phosphorus levels and insulin-like growth factor-1 in chinese children and adolescents with short stature. Int J Gen Med. 2020; 13: 1168-1173. https://doi.org/10.2147/ijgm.s276261

3. Calvo MS, Uribarri J. Public health impact of dietary phosphorus excess on bone and cardiovascular health in the general population. Am J Clin Nutr. 2013; 98(1): 6-15. https://doi.org/10.3945/ajcn.112.053934

4. Kołłątaj W, Kołłątaj B, Klatka M, Wrzołek K, Krzewska A. Witamina D - rekomendacje czy też konieczność indywidualizacji dawek? Endokrynol Pediatr. 2015; 14.1.50: 11-21. https://doi.org/10.18544/ ep-01.14.01.1506

5. Hoel DG, Berwick M, de Gruijl FR, et al. The risks and benefits of sun exposure 2016. Dermatoendocrinol. 2016; 8: e1248325. https://doi.org /10.1080/19381980.2016.1248325
6. Theodoratou E, Tzoulaki I, Zgaga L,Ioannidis JPA. Vitamin D and multiple health outcomes: umbrella review of systematic reviews and meta-analyses of observational studies and randomised trials. BMJ. 2014; 348. https://doi.org/10.1136/bmj.g2035

7. Zempleni J, Rucker RB, Suttie JW, Mc Cormick DB, editors. Handbook of Vitamins, 4th Edition. CDC Press Taylor \& Francis Group; 2007.

8. Autier P, Boniol M, Pizot C, Mullie P. Vitamin D status and ill health: a systematic review. Lancet Diabetes Endocrinol. 2014; 2: 76-89. https:// doi.org/10.1016/s2213-8587(13)70165-7

9. Garganta, Melissa D, Bremer AA. Clinical dilemmas in evaluating the short child. Pediatrics Annals. 2014; 43: 321-327. https://doi. org/10.3928/00904481-20140723-11

10. Sultan M, Afzal M, Qureshi SM. Etiology of short stature in children. J Coll Physicians Surg Pak. 2008; 8: 493-497. http://dx.doi. org/10.18203/2349-3291.ijcp20200110

11. Matsumoto R, Masafumi K, Soji K, Hidenori F, Genzo J, et al. Factors correlated with serum insulin-like growth factors-I levels in health check-up subjects. Growth Hormone \& IGF Research. 2018; 40: 55-60. https://doi.org/10.1016/j.ghir.2018.01.003

12. Oświęcimska J, Roczniak W, Mikołajczak A, Szymlak A. Niedobór hormonu wzrostu u dzieci i młodych dorosłych. Adv Hyg Exp Med Hig Med Dośw. 2016, 70.

13. AL Bueno, MA Czepielewski, Raimundo FV. Calcium and vitamin D intake and biochemical tests in short-stature children and adolescents. Eur J Clin Nutrit. 2010; 64: 1296-1301.

14. Weaver CM, McCabe LD, Braun M, Martin BR, DiMeglio LA, Peacock M. Vitamin D status and calcium metabolism in adolescent black and white girls on a range of controlled calcium intakes. J Clin Endocrinol Metab. 2008; 93: 3907-3914.

15. Bauer DC. Calcium supplements and fracture prevention. New Engl J Med. 2014; 370.4: 387-388. doi: 10.1056/NEJMc1314100

16. Dembińska-Knieć A, Naksalski J. Diagnostyka laboratoryjna z elementami biochemii klinicznej. Edra; 2017.

17. Rusińska A, et al. Zasady suplementacji i leczenia witaminą D nowelizacja 2018. Postępy Neonatol. 2018; 24/1: 1-24. https://doi. org/10.31350/postepyneonatologii/2018/1/pn201800

18. Esposito S, Leonardi A, Lanciotti L, Cofini M, Muzi G, Penta L. Vitamin $\mathrm{D}$ and growth hormone in children: a review of the current scientific knowledge. J Transl Med. 2019; 17(1): 87. https://doi.org/10.1186/s12967019-1840-4

19. Rodakowska E, Wilczynska-Borawska M, Baginska J, et al. Epidemiological analysis of dental caries in 12-year-old children residing in urban and rural settings in the Podlaskie region of northeastern Poland. Ann Agric Environ Med. 2013; 20: 325-8.

20. Gordom CM, De Peter KC, Feldman HA, Grace E, Emans J. Prevalence of vitamin D deficiency among healthy adolescents. Arch. Pediatr Adolesc Med. 2004; 158(6): 531-537. https://doi.org/10.1001/archpedi.158.6.531

21. Żak T, Basiak A, Zubkiewicz-Kucharska A, Noczyńska A. Ocena szybkości wzrastania i gospodarki wapniowo-fosforanowej, gęstości mineralnej kości oraz zmiana składu ciała u dzieci z somatotropinową niedoczynnością przysadki w pierwszym roku leczenia rekombinowanym ludzkim hormonem wzrostu(rhGH). Pediatr Endocrinol Diabetol Metab. 2010; 16(1): 39-43. Urban \& Partner, 2010

22. Sun M, Yan W, Zhao Q, Ji B, Ban B, Zhang M. Association between serum calcium and phosphorus levels and insulin-like growth factor-1 in chinese children and adolescents with short stature. Int J Gen Med. 2020; 13: 1168-1173. https://doi.org/10.2147/ijgm.s276261

23. Khadilkar V, Ekbote V, Chiplonkar S, Khadilkar A. Bone mineral content in growth hormone deficient children treated with growth hormone after withdrawal of 1 year of supplementation with calcium, vitamin D and zinc. Int J Pediatr Endocrinol. 2015; 1: 1-1. https://doi. org/10.1007/s12020-015-0582-1

24. Durá-Travé T, Gallinas-Victoriano F, Moreno-González P, Urretavizcaya-Martinez M, Berrade-Zubiri S, Chueca-Guindulain MJ. Vitamin D status and response to growth hormone treatment in prepubertal children with growth hormone deficiency. J Endocrinol Invest. 2020; 43(10): 1485-1492. https://doi.org/10.1007/s40618-02001227-3

25. Ciresi A, Cicciò F, Giordano C. High prevalence of hypovitaminosis $\mathrm{D}$ in Sicilian children affected by growth hormone deficiency and its improvement after 12 months of replacement treatment. J Endocrinol Invest. 2014; 37(7): 631-8. https://doi.org/10.1007/s40618-014-0084-7

26. Savanelli MC, Scarano E, Muscogiuri G, Barrea L, Vuolo L, et al. Cardiovascular risk in adult hypopituitaric patients with growth hormone deficiency: is there a role for vitamin D? Endocrine. 2016; 52: 111-119. https://doi.org/10.1007/s12020-015-0779-3 
27. Karczmarewicz E, Czekuc-Kryskiewicz E, Płudowski P. Effect of vitamin D status on pharmacological treatment efficiency: Impact on cost-effective management in medicine. Dermatoendocrinol. 2013; 5 : 299-304. https://doi.org/10.4161/derm.25279

28. Rasha Tarif Hamza, Amira I Hamed, Mahmoud T Sallam. J Investig Med. 2018 Jun; 66(5): 1-8. Vitamin D status in prepubertal children with isolated idiopathic growth hormone deficiency: effect of growth hormone therapy. doi: 10.1136/jim-2017-000618. Epub 2018 Feb 24.

29. Veugelers P, Pham T-M, Ekwaru J. Optimal Vitamin D Supplementation Doses that Minimize the Risk for Both Low and High Serum 25-Hydroxyvitamin D Concentrations in the General Population. Nutrients. 2015; 7: 10189-10208. doi: 10.3390/nu7125527

30. Pramyothin P, Holick MF. Vitamin D supplementation: guidelines and evidence for subclinical deficiency. Curr. Opin. Gastroenterol. 2012; 28: 139-150. doi: 10.1097/MOG.0b013e32835004dc

31. Absound M, Cummins C, Lim MJ, Wassmer E, Shaw N. Prevelance and predictors of vitaminD insufficiency in children: a Great Britain population Based study. PLoS One. 2011; 6(7): e22179. https://doi. org/10.1371/journal.pone.0022179

32. Ryan LM, Brandoli C, Freishtat RJ, Wright JL, Tosi L, Chamberlain JM. Prevalence of vitamin D insufficiency in African American children with forearm fractures: a preliminary study. J Pediatr Orthop. 2010; 30(2): 106-109. https://doi.org/10.1016/j.bone.2007.04.106

33. Van der Meer IM, Middelkoop BJC, Boeke AJP, Lips P. Prevelence of vitamin deficiency among Turkish, Maroccan, Indian and subSahara African populations in Europe and their countries of origin: an overview. Osteoporos Int. 2011; 22(4): 1009-1021. https://doi. org/10.1007/s00198-010-1279-1

34. Khadilkar AV. Vitamin D deficiency in Indian adolescents. Indian Pediatr. 2010; 47: 755-6. https://doi.org/10.1007/s13312-010-0110-6

35. Hypponen E, Laara E, Reunanen A, Jarvelin MR, Virtanen SM. Intake of vitamin D and risk of type I diabetes: a birthcohort study. Lancet. 2001; 358: 1500-3. https://doi.org/10.1016/s0140-6736(01)06580-1

36. Camargo CA Jr, Rifas-Shiman SL, Litonjua AA, Rich-Edwards JW, Weiss ST, Gold DR, et al. Maternal intake of vitamin D during pregnancy and risk of recurrent wheeze in children at 3 y of age. Am J Clin Nutr. 2007; 85: 788-96. https://doi.org/10.1093/ajcn/85.3.788

37. Litonjua AA. Childhood asthma may be a consequence of vitamin D deficiency. Curr Opin Allergy Clin Immunol. 2009; 9: 202-7. https:// doi.org/10.1097/aci.0b013e32832b36cd

38. Munger KL, Levin LI, Hollis BW, Howard NS, Ascherio A. Serum 25 hydroxyvitamin D levels and risk of multiple sclerosis. Jama. 2006; 296: 2832-8. https://doi.org/10.1001/jama.296.23.2832

39. Merlino LA, Curtis J, Mikuls TR, Cerhan JR, Criswell LA, Saag KG. Vitamin D intake is inversely associated with rheumatoid arthritis: results from the Iowa Women's Health Study. Arthritis Rheum. 2004; 50: 72-7. https://doi.org/10.1002/art.11434

40. Garland CF, Garland FC, Gorham ED, Lipkin M, Newmark H, Mohr SB. The role of vitamin in cancer prevention. Am J Public Health. 2006; 96: 252-61. https://doi.org/10.2105/AJPH.2004.045260

41. Lappe JM, Travers-Gustafson D, Davies KM, Recker RR, Heaney RP. Vitamin D and calcium supplementation reduces cancer risk: Results of randomized trial. Am J Clin Nutr. 2007; 85: 1586-91. 